\title{
PENGUATAN LITERASI INFORMASI BERBASIS PERPUSTAKAAN BAGI PENINGKATAN MUTU AKADEMIK MAHASISWA PGMI IAIN CIREBON
}

\author{
Atikah Syamsi \\ Email : atikahsy@syekhnurjati.ac.id
}

\begin{abstract}
This study aims to determine: 1) How Information Literacy Strengthening Program for students in primary IAIN Cirebon. 2) Strengthening Program Implementation Based Information Literacy Libraries For students in primary IAIN Cirebon. 3) Strengthening the Effectiveness of Information Literacy Library Based on Academic Quality Improvement in primary students IAIN Cirebon.

This research is classroom action research. The stages in the cycle of action research are: Planning, Implementation of the action, Observations and Reflections. The location research is on PGMI S1 IAIN SNJ Cirebon by using purposive sampling. The technique of collecting data through observation, interviews, questionnaires and tests. Given the Action Research study using a combined approach of qualitative and quantitative. The data analysis starts from the field by using descriptive analytic method that is compiled by describing, interpreting the data and analyze all the things that are the focus of this research.

The results showed that: 1) Based on the results of observations and Collecting data elements that must be considered in implementing the information literacy program, the target or targets, the needs of students, the method to be used, the material to be conveyed, human resources and facilities that support the technology. 2) Strengthening program implementation based library information literacy is integrated in teaching and learning activities in the classroom. 3) There is an increased effective against academic grades of students in primary after they were given reinforcement program of action based library information literacy
\end{abstract}

Keywords: Strengthening, Information Literacy, Academic Quality

\begin{abstract}
Abstrak
Penelitian ini bertujuan untuk mengetahui: 1) Bagaimana Program Penguatan Literasi Informasi Bagi mahasiswa PGMI IAIN Cirebon. 2) Implementasi Program Penguatan Literasi Informasi Berbasis Perpustakaan Bagi mahasiswa PGMI IAIN Cirebon. 3) Efektifitas Penguatan Literasi Informasi Berbasis Perpustakaan terhadap Peningkatan Mutu Akademik mahasiswa PGMI IAIN Cirebon.

Penelitian ini merupakan penelitian Tindakan Kelas dengan tahapan siklus: perencanaan, penerapan, observasi dan refleksi. Penelitia mengambil lokasi di S1 PGMI IAIN SNJ Cirebon dengan menggunakan metode sampel bertujuan. Pengambilan data menggunakan metode obserfasi, wawancara, kuesionair dan tes. Analisis data yang digunakan merupakan kombinasi antara pendekatan kualitatif dan kuantitatif.

Hasil penelitian menunjukkan bahwa, 1)Unsur yang harus diperhatikan dalam melaksanakan program literasi informasi, yakni target atau sasaran, kebutuhan mahasiswa, metode yang akan digunakan, materi yang akan disampaikan, sumber daya manusia serta fasilitas teknologi yang mendukung. 2) Implementasi program penguatan literasi informasi berbasis perpustakaan ini terintegrasi dalam kegiatan belajar mengajar di kelas. 3) Terdapat peningkatan yang efektif terhadap nilai akademis mahasiswa PGMI setelah mereka diberikan tindakan program penguatan literasi informasi berbasis perpustakaan
\end{abstract}




\section{PENDAHULUAN}

Dewasa ini dimana era globalisasi adalah era persaingan mutu atau kualitas dari suatu produk, maka produk yang bermutu akan diminati oleh konsumen, sebaliknya apabila produk itu tidak bermutu maka akan ditinggalkan oleh konsumen. Hal ini pun berlaku pula dalam dunia pendidikan, sehingga perguruan tinggi di era globalisasi harus berbasis pada mutu, dan memiliki diferensiasi dalam kegiatan jasa pendidikan maupun pengembangan sumber daya manusia yang memiliki keunggulan-keunggulan dan tentunya berbeda dengan perguruan tinggi lainnya. Masyarakat mengharapkan mahasiswa yang sedang menuntut ilmu di perguruan tinggi mempunyai nilai ganda yaitu ilmu pengetahuan, gelar, ketrampilan, pengalaman, keyakinan dan perilaku luhur yang mampu bersaing dipasar global. Nilai-nilai tersebut sebagai persiapan memasuki dunia kerja dan atau persiapan membuka lapangan kerja dengan mengharapkan kehidupan yang lebih baik dan kesejahteraan lahir serta batin.

Kenyataan yang ada pada dewasa ini menunjukkan mutu lulusan perguruan tinggi itu tidak selalu dapat diterima dan mampu untuk bekerja sebagaimana yang diharapkan dunia kerja. Maraknya perguruan tinggi berpotensi merosotnya mutu lulusan, mengingat standarisasi mutu lulusan tidak menjadi tujuan; tetapi hanya dilihat dari aspek kuantitas; yakni bagaimana mendapatkan jumlah mahasiswa sebanyak-banyaknya. Tuntutan terhadap lulusan lembaga pendidikan yang bermutu semakin ketat karena semakin maraknya persaingan dalam lapangan kerja. Salah satu implikasi globalisasi dalam pendidikan yaitu adanya deregulasi yang memungkinkan peluang lembaga pendidikan termasuk perguruan tinggi asing untuk membuka sekolahnya di Indonesia. Oleh karena itu persaingan antar lembaga pendidikan dan pasar kerja akan semakin berat.

Demi mengantisipasi perubahanperubahan yang begitu cepat serta tantangan yang semakin besar dan kompleks, maka lembaga pendidikan seharusnya mengupayakan segala cara untuk meningkatkan daya saing lulusan serta produk-produk akademik lainnya, yang antara lain dicapai melalui peningkatan mutu pendidikan.

Berdasarkan Survei Angkatan Kerja Nasional Februari Tahun 2013 yang dilakukan Biro Pusat Statistik ditemukan bahwa lapangan kerja Indonesia masih didominasi oleh lulusan Sekolah Dasar dan Sekolah Menengah Pertama. Sebanyak 54,6 juta orang, atau 47,90 persen dari total 114,02 juta pekerja hanya berpendidikan Sekolah Dasar. Bandingkan dengan pekerja lulusan Diploma sebanyak 3,2 juta orang (2,82 persen), atau Sarjana yang hanya 8,0 juta orang $(6,96$ persen $)$. (www.bps.go.id)

Salah satu faktor yang sangat berpengaruh terhadap daya saing suatu bangsa adalah pendidikan masyarakatnya. Pendidikan memiliki peran strategis dalam pembangunan bangsa serta memberi kontribusi siginifikan bagi pertumbuhan ekonomi dan transformasi 
sosial. Masyarakat dengan pendidikan yang baik akan dapat meningkatkan produktivitas dan pendapatannya, yang secara kolektif akan meningkatkan pendapatan negara. Saat ini, dan di masa mendatang, sumber daya alam bukan lagi menjadi daya saing utama suatu bangsa, melainkan penguasaan atas ilmu pengetahuan dan teknologi.

Pendidikan sebagai suatu proses, pertama mengenal adanya raw-input dan instrumental input. Raw input merupakan peserta didik sedangkan instrumental input terdiri dari : gedung, perpustakaan, pedoman akademik, dosen, kurikulum, metode dan lainlain. Kedua raw input dan instrumental input masuk dalam proses, yang ini akan memakan waktu delapan (8) semester. Ketiga, output (hasil didik) yang sesuai dengan kriteria institusi dan siap untuk masuk kedalam persaingan sumber daya manusia. Dosen sebagai tenaga pengajar merupakan instrumen yang sangat menentukan keberhasilan proses pendidikan, karena dari tenaga pengajar lah perpindahan ilmu dilakukan kepada peserta didik.

Perguruan tinggi yang memiliki tenagatenaga pengajar berkualitas akan banyak diminati oleh masyarakat. Salah satu indikator system pengajaran dikatakan berkualitas yaitu manakala tercipta sisi akademis baik itu dalam menghasilkan karya, bersikap dan juga bernalar. Karya yang dimaksud ialah berupa karya tulis maupun non tulis, dimana karya tulis yang seharusnya digunakan oleh para akademisi selalu merujuk kepada hal-hal yang bersifat ilmiah. Keilmiahan ini ditunjukkan dengan terdapatnya indikator rujukan terhadap literatur-literatur yang dapat dipertanggungjawabkan, dalam hal ini merujuk kepada buku-buku ataupun arsip serta dokumen yang berada pada sumber belajar yang harus ada pada Perguruan Tinggi yakni perpustakaan. Berdasar pengalaman mengajar \& pengamatan sejak tahun 2011 selama ini pada jurusan PGMI di IAIN SNJ Cirebon, mahasiswa PGMI banyak yang mengalami degradasi dalam minat baca serta dalam minat menggunakan literature buku sebagai literasi informasi dan referensi dalam tiap karya mereka,hasil wawancara singkat dengan beberapa mahasiswa menunjukkan bahwa mereka lebih cenderung untuk menggunakan internet sebagai media pembantu pada karya tulis mereka. (Berdasarkan hasil wawancara dengan mahasiswa pada perkuliahan awal semester) Buku-buku sebagai literasi informasi yang bisa dipertanggungjawabkan seringkali mereka tinggalkan karena habit mereka yang jarang berinteraksi dengan buku dan keresahan ini bukan saja terjadi pada satu atau dua mata kuliah, melainkan dalam beberapa mata kuliah seperti yang sudah peneliti amati. Hal ini tentu saja menjadi kegamangan bagi peneliti sehingga kami terbesit untuk melakukan penelitian mengenai "penguatan literasi informasi berbasis perpustakaan bagi mahasiswa PGMI menuju peningkatan mutu akademik lulusan” 
Berdasarkan pada latar belakang diatas, maka penulis mengajukan beberapa rumusan masalah yang akan dikaji lebih lanjut, yaitu :

1. Bagaimana program penguatan literasi informasi bagi mahasiswa PGMI IAIN Cirebon?

2. Bagaimana implementasi program penguatan literasi informasi berbasis perpustakaan bagi mahasiswa PGMI IAIN Cirebon?

3. Bagaimana efektifitas penguatan literasi informasi berbasis perpustakaan terhadap peningkatan mutu akademik mahasiswa PGMI IAIN Cirebon?

\section{LANDASAN TEORI}

\section{a. Kompetensi \\ Program Literasi Informasi}

Literasi informasi merupakan suatu ketrampilan yang sangat penting untuk dikuasai, terutama di era globalisasi saat ini. Menurut American Library Association (ALA, 1998) dikatakan bahwa orang yang melek informasi adalah orang yang mampu menyadari kapan informasi diperlukan dan bahkan juga mempunyai kemampuan untuk menemukan, mengevaluasi dan menggunakan informasi tersebut secara efektif. Literasi informasi juga merupakan pra-syarat dalam masyarakat informasi dan merupakan hak asasi manusia untuk belajar sepanjang hayat. (Perpustakaan Nasional RI, 2007:15)

Literasi informasi penting untuk dikuasai oleh peserta didik di sekolah maupun di perguruan tinggi, karena literasi informasi mengajarkan bagaimana menemukan dan menggunakan informasi yang diperlukan sehingga mampu menunjang proses pembelajaran. Perpustakaan sebagai lembaga penyedia dan pengelola informasi memiliki peran penting terhadap pengembangan literasi informasi. Salah satu cara yang dapat dilakukan perpustakaan dalam pengembangan literasi informasi adalah dengan memberikan pendidikan pada pemakai (User) dengan fokus pada pengembangan literasi informasi pengguna. Program pendidikan pemakai di perpustakaan harus diarahkan pada pencapaian literasi informasi penggunanya (Naibaho, 2007:12).

\section{b. Urgensi Perpustakaan Dalam Literasi Informasi di Perguruan Tinggi}

Dalam era globalisasi, hampir setiap orang dalam kegiatannya tidak dapat terlepas dari informasi, karena informasi telah menjadi kebutuhan primer masyarakat. Setiap aspek kehidupan dihubungkan dengan ketersediaan informasi (Artana, 2003:1). Kemajuan teknologi informasi mendorong masyarakat industri (industry society) pelan-pelan beralih ke masyarakat informasi (information society). Hal itu menunjukkan bahwa informasi telah mendapatkan tempat yang penting dalam aktivitas masyarakat. Kenyataan menunjukkan bahwa banyak orang mencari informasi. Hal tersebut berarti, permintaan terhadap informasi begitu penting sehingga informasi memiliki nilai ekonomi yang tinggi pula. 
Godwin (2008:5) menyebut generasi saat ini sebagai "generasi web" atau "generasi Google”. Generasi Google menganggap apa yang tertulis dan tercantum di web pasti benar Perilaku dalam memperoleh informasi yang sudah ditemukan juga patut menjadi perhatian. Generasi Google ini, menurut Godwin, tidak mempedulikan etika dalam penggunaan isi dari sumber-sumber itu karena mereka tidak paham atau tidak peduli terhadap isi maupun akurasi sumber datanya. (Godwin, 2008:6) Mereka menganggap penggunaan informasi yang dibutuhkan dengan menerapkan perilaku copy and paste merupakan hal yang biasa dan tidak menyadari bahwa informasi yang diperoleh ini seharusnya perlu dibaca ulang dan diolah terlebih dahulu serta dipastikan kebenarannya sebelum akhirnya digunakan dan dipublikasikan pada khalayak.

Meskipun informasi saat ini melimpah namun informasi tersebut tidak sepenuhnya dapat digunakan atau dimanfaatkan, terutama dijadikan bahan referensi oleh kaum akademisi. Achmad (2007:1) menyatakan bahwa informasi yang bernuansa negatif justru lebih banyak terakses dari pada informasi yang positif. Oleh karena itu Carr (2011:180) menghimbau agar pengguna informasi dapat memilih dan memilah informasi yang sesuai dengan apa yang kita butuhkan. Ketrampilan tersebut disebut sebagai "literasi informasi".

Farmer \& Henri mengungkapkan pula bagaimana literasi informasi memberikan pengaruh pada kegiatan membaca siswa. Selain dapat meningkatkan reading comprehension para peserta didik, literasi informasi yang diintegrasikan dan dirancang secara kolaboratif dalam kegiatan akademisi akan meningkatkan kemampuan pembelajaran dan produk penelitian mereka. Lebih dari itu, para peserta didik yang diajarkan kompetensi program literasi informasi secara berkelanjutan akan lebih sukses dalam pendidikan tingginya daripada mereka yang tidak mendapatkan pengetahuan dan pengalaman literasi itu sebelumnya (Farmer \& Henri, 2008 :16)

\section{c. Peningkatan Mutu Akademik Mahasiswa}

Soehendro (1996) mengemukakan bahwa upaya manajemen kualitas pendidikan dapat dilakukan dengan cara menyesuaikan sasaran pendidikan dengan kebutuhan tenaga kerja ahli. Untuk meningkatkan kualitas pendidikan, proses pembelajaran harus diberdayakan semaksimal mungkin (Kurniawan, 2003). Pemberdayaan ini dilakukan antara lain dengan cara : (1) mengubah paradigma masyarakat pembelajar, (2) mengembangkan resources dan mengembangkan content . Masyarakat lembaga pendidikan harus diberikan pengertian tentang proses pendidikan dan pembelajaran, yaitu bahwa budaya teacher centered harus diganti dengan budaya student activity. Mahasiswa adalah pelaku belajar, bukan pihak yang dijejali dengan materi belajar.

Dosen bertindak sebagai fasilitator yang kehadirannya menyebabkan mahasiswa 
JPSD : Jurnal Pendidikan Sekolah Dasar Vol. 2, No. 2 Agustus 201629

mempunyai keinginan belajar. Sumber daya pendidikan (pengajar serta alat belajar lain) harus pula dikembangkan, dengan cara pembinaan dan pengembangan kemampuan pengajar, peningkatan literasi informasi, persiapan sarana dan prasarana pembelajaran serta penyiapan fasilitas teknologi informasi yang mendukung proses pembelajaran.

\section{METODE PENELITIAN}

\section{Jenis \& Metode Penelitian}

Penelitian tindakan kelas ini dilakukan untuk mengintrospeksi, bercermin, merefleksi atau mengevaluasi tujuan kegiatan belajar yang diharapkan. Dari peningkatan kemampuan tersebut diharapkan dapat berpengaruh terhadap peningkatan kualitas literasi mahasiswa, baik dalam aspek penalaran, keterampilan, mencari rujukan maupun aspekaspek lain yang bermanfaat bagi mahasiswa.

Dalam melakukan penelitian tindakan kelas ini peneliti menggunakan siklus Kemmis sebagai rencana tindakan dalam penelitian tindakan kelas, sebagaimana yang tertuang dalam penjelasan sebelumnya

Gbr. 4

Siklus kemmis (dalam Mulyasa, 2009 :112)

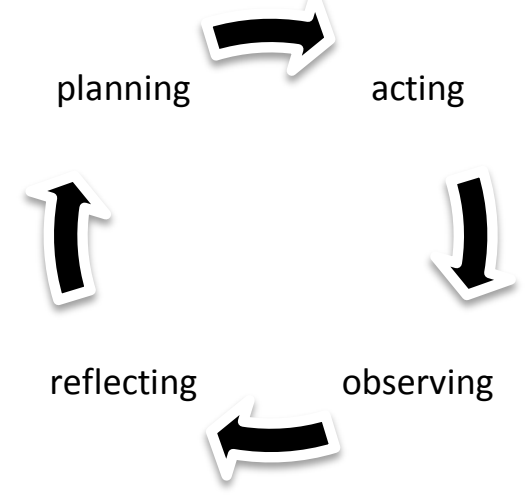

\section{Tehnik Sampling}

Penelitian ini dilakukan pada mahasiswa S1 PGMI IAIN SNJ Cirebon dengan menggunakan purposive sampling. Adapun untuk subjek informannya ialah mahasiswa dengan mata kuliah dan jenjang tertentu yang diampu oleh masing-masing instruktur yang dalam hal ini adalah Dosen Pengampunya, sehingga diharapkan dapat memberikan informasi secara akurat dan berkelanjutan.

\section{Tehnik Pengumpulan Data}

Untuk memperoleh data dalam penelitian ini, penulis menggunakan beberapa tehnik dalam pengumpulan datanya, antara lain

\section{a. Observasi}

Pada penelitian ini digunakan observasi sebagai teknik pengumpulan data dan lembar observasi sebagai instrumen pengumpulan datanya.

\section{b. Wawancara Mendalam}

Wawancara atau interview dilakukan kepada mahasiswa yang diampu oleh masingmasing Peneliti. Interview yang digunakan dalam metode ini adalah interview semi struktur. Maksudnya tidak seperti penelitian kuantitatif yang menggunakan metode wawancara terstruktur, karena penelitian kualitatif lebih cenderung dengan pertanyaan yang bersifat mendalam, (Mikkelsen, 2001), sehingga dalam pelaksanaannya tetap menggunakan metode terpimpin dimana peneliti terlebih dulu mempersiapkan kuesioner yang akan diajukan kepada informan (interview 
guide), tetapi penyampaian pertanyaannya bisa secara bebas.

\section{c. Kuesioner}

Kuesioner yang peneliti lakukan menggunakan kontak langsung antara peneliti dengan responden, sehingga dapat tercipta suasana dan kondisi yang cukup baik yaitu responden dengan sukarela memberikan data yang obyektif dan cepat.

\section{d. Tes}

Teknik ini digunakan untuk mengetahui seberapa luas pengetahuan dan kemampuan mahasiswa terkait literasi informasi. Tes ini juga dapat dilakukan untuk mengetahui hasil atau efektifitas treatment setelah diberikan kepada mahasiswa. Hal ini hampir mirip seperti triangulasi data sementara. Tehnik ini memang tidak lazim digunakan, bahkan pada kebanyakan literatur metodologi penelitian seringkali tidak mencantumkan teknik ini sebagai salah satu teknik pengumpulan data namun peneliti akan membahasnya karena hal ini dirasa cukup representative sesuai dengan prinsip dalam penelitian eksperimen.

\section{Tehnik Analisis Data}

Mengingat dalam penelitian Action Research ini menggunakan pendekatan gabungan dari kualitatif dan kuantitatif, maka analisis data dimulai dari lapangan dengan menggunakan metode deskriptif analitik yaitu menyusun dengan cara mendeskripsikan, menafsirkan data dan menganalisa semua hal yang menjadi fokus dalam penelitian ini. Data kuantitatif terlebih dahulu dilakukan tabulasi secara prosentase untuk mengetahui jumlah skor akhir dari tiap aspek pertanyaan dalam angket yang diperoleh dari hasil tes siswa secara individu kemudian diolah dengan mencari rata-ratanya.

Adapun Kriteria tingkat keberhasilan aktivitas/respon siswa menurut Sudjana (2004:78)

\begin{tabular}{|c|c|c|}
\hline Ketuntasan & belajar & klasikal \\
\hline skor yang $\mathrm{c}$ & nakan & X $100 \%$ \\
\hline
\end{tabular}

\section{Tabel Nilai Skoring}

\begin{tabular}{|c|c|c|c|}
\hline $\begin{array}{c}\text { Pencapai } \\
\text { an } \\
\text { Tujuan }\end{array}$ & $\begin{array}{c}\text { Sko } \\
\text { r }\end{array}$ & $\begin{array}{c}\text { Kualifika } \\
\text { si }\end{array}$ & $\begin{array}{c}\text { Keberhasil } \\
\text { an }\end{array}$ \\
\hline $85-100 \%$ & 3 & Baik & Berhasil \\
\hline $70-84 \%$ & 2 & Cukup & $\begin{array}{c}\text { Cukup } \\
\text { Berhasil }\end{array}$ \\
\hline $50-69 \%$ & 1 & Kurang & $\begin{array}{c}\text { Tidak } \\
\text { Berhasil }\end{array}$ \\
\hline
\end{tabular}

Keterangan :

$$
\begin{aligned}
& \text { 85-100\% = Berhasil } \\
& 70-84 \%=\text { Cukup Berhasil } \\
& 50-69=\text { Tidak Berhasil }
\end{aligned}
$$

Sebagian besar tehnik pengumpulan data dalam penelitian ini menggunakan analisa data non statistik, maka sebagian besar deskripsi data-datanya melalui bentuk kata-kata atau kalimat yang akan digunakan secara sistematis. Adapun langkah-langkah teknik analisis datanya sebagai berikut :

a. Reduksi data

Data yang diperoleh disusun secara sistematis kemudian dianalisis sejak dimulai penelitian. Data-data tersebut perlu direduksi, yaitu dengan memilih hal-hal pokok yang sesuai 
JPSD : Jurnal Pendidikan Sekolah Dasar Vol. 2, No. 2 Agustus 201631

dengan tujuan penelitian. Data-data yang telah direduksi memberikan gambaran yang lebih tajam tentang hasil pengamatan dan lebih mempermudah penulis untuk menelusuri data tersebut berasal dari sumber mana, hal ini biasa dikenal juga dengan istilah koding data.

b. Display data

Display data dilakukan untuk menyajikan hasil data yang semakin banyak dan bertumpuk ke dalam bentuk matrik.

c. Pengambilan kesimpulan dan verifikasi

Pengambilan kesimpulan yang dilakukan pertama kali oleh peneliti mula-mula kabur, tetapi lama-kelamaan kesimpulan tersebut akan semakin jelas karena data yang diperoleh semakin banyak dan mendukung. Verifikasi dapat dilakukan dengan singkat yaitu dengan cara mengumpulkan data baru.

\section{Teknik Keabsahan Data}

Untuk keperluan pemeriksaan keabsahan data, peneliti menggunakan teknik pemeriksaan triangulasi. Adapun teknik triangulasi yang peneliti gunakan adalah dengan teknik pemeriksaan yang memanfaatkan penggunaan sumber, yang berarti membandingkan dan mengecek balik derajat kepercayaan suatu informasi yang diperoleh melalui waktu dan alat yang berbeda dalam metode kualitatif.

Dalam penelitian ini, untuk keperluan pemeriksaan keabsahan data, penulis menggunakan teknik pemeriksaan triangulasi yang dilakukan dengan jalan membandingkan data hasil pengamatan dengan kuesioner dan wawancara. Hal tersebut dilakukan dengan maksud supaya data atau informasi yang diperoleh sewaktu peneitian benar-benar valid dan dapat dipertanggungjawabkan secara ilmiah.

HASIL DAN PEMBAHASAN

a) Program Literasi Informasi Mahasiswa PGMI IAIN Cirebon

Seperti yang telah diketahui bersama bahwa UNESCO menekankan pentingnya mengintegrasikan keterampilan informasi ke dalam tiga keterampilan dasar literasi yang dikenal sebelumnya: membaca (reading), menulis (writing), berhitung (arithmatic) dan meneliti (research) untuk pendidikan Tinggi, maka dengan bekal kemampuan literasi tersebut, setiap orang diharapkan memperoleh kesempatan untuk berpartisipasi dan mendapatkan manfaat dari perkembangnya di era informasi saat ini. Dengan kata lain, merujuk kepada salah satu definisi yang diberikan oleh UNESCO pada halaman sebelumnya, maka literasi informasi yang kami maksudkan ialah kemampuan mengidentifikasi, menemukan, mengevaluasi, mengorganisasikan dan menggunakan informasi tersebut secara efektif untuk menjawab dan membantu menyelesaikan masalah/isu sosial yang lebih luas.

Berdasar hasil observasi dan Collecting data yang dikumpulkan, Unsur yang harus diperhatikan dalam melaksanakan program literasi informasi, yakni target atau sasaran, kebutuhan mahasiswa, metode yang akan digunakan, materi yang akan disampaikan, sumber daya manusia, fasilitas teknologi yang 
mendukung. Adapun beberapa langkahlangkah dalam memperoleh kemampuan program literasi informasi yaitu:

a) Merumuskan kebutuhan informasi

Pada awal program mahasiswa diminta untuk merumuskan kebutuhan informasi, dimana hal ini merupakan tahap awal dalam melakukan penelusuran informasi. Kegunaan dari identifikasi informasi adalah supaya mahasiswa mengetahui apa kegunaan informasi yang dicari misalnya untuk pendidikan, kesehatan atau bahkan hubungan dengan masyarakat. Terkait dengan responden kami, mereka kami minta untuk merumuskan terkait pendidikan sains di MI dan juga terkait materi kewirausahaan.

b) Mengalokasikan dan mengevaluasi kualitas informasi.

Langkah berikutnya yaitu mahasiswa mengalokasikan informasi dapat dilakukan dengan cara manual atau bisa juga dibuat portfolionya sehingga manakala suatu saat diperlukan bisa ditemukan kembali. Kualitas dari informasi dapat dilihat dari penggunaan informasi tersebut dan kredibilitas dari informasi tersebut. Apabila kriteria informasi dipenuhi oleh suatu informasi maka kualitasnya semakin baik. Hal tersebut terlihat dari hasil kinerja mahasiswa, yaitu mereka yang dengan baik melakukan program literasi ini maka hasil kerja serta produk yang mereka buat juga berhasil dengan baik.

c) Menyimpan dan menemukan kembali informasi.
Setelah mahasiswa mengalokasikan informasi dengan baik, mereka harus mampu menyimpan informasi yang sudah diperoleh agar suatu saat informasi tersebut mudah ditemukan kembali ketika akan digunakan. Penyimpanan dapat dilakukan dengan menggunakan sistem manual maupun elektronik.

d) Menggunakan informasi secara efektif dan efisien.

Kemampuan ini digunakan agar mahasiswa mampu menggunakan informasi yang diperoleh secara efektif dan efisien. Mereka diminta untuk menuliskan kembali hasil penelusurannya dalam sebuah mind map dan berdasar pada hasil temuan dari referensi yang telah mereka temukan dari perpustakaan atau pun dari toko buku yang menjadi setting sumber belajar dalam program ini.

e) Mengkomunikasikan pengetahuan.

Kemampuan ini bertujuan untuk meningkatkan kompetensi mahasiswa dalam menciptakan pengetahuan baru dan menyebarkan atau mengkomunikasikan kepada orang lain yang membutuhkan informasi tersebut berdasar pada sumber data atau bacaan yang telah mereka adopsi serta harus tercantum dalam hasil temuan mereka.

\section{b) Implementasi Program Penguatan} Literasi Informasi Berbasis Perpustakaan Bagi Mahasiswa PGMI IAIN Cirebon

Implementasi program penguatan literasi informasi berbasis perpustakaan ini terintegrasi dalam kegiatan belajar mengajar di 
JPSD : Jurnal Pendidikan Sekolah Dasar Vol. 2, No. 2 Agustus 201633

kelas. Peneliti menggunakan optimalisasi Perpustakaan yang tidak hanya di kampus IAIN Cirebon, namun juga perpustakaan Daerah satu-satunya di Kota Cirebon, selain itu peneliti juga memanfaatkan Toko Buku Nasional Terbesar di Kota Cirebon untuk mengakses buku-buku terbaru sehingga hal ini dapat menjadi kegiatan penunjang keterampilan literasi informasi bagi mahasiswa PGMI. Keterampilan ini kemudian diterapkan oleh mahasiswa saat mereka mengerjakan tugas-tugas yang diberikan oleh Dosen bidang mata kuliah yang diajarkan dan target besarnya supaya berdampak pula pada mata kuliah lainnya di Jurusan PGMI.

Implementasi Program Penguatan Literasi Informasi dimulai dari beberapa tahapan yaitu :

1) Perencanaan program; Rencana program penguatan Literasi Informasi berbasis perpustakaan ini dimulai dengan mengamati teknik pembelajaran yang digunakan sebelumnya kemudian melakukan kegiatan identifikasi faktor hambatan dan kemudahan terhadap teknik pembelajaran tersebut, sehingga langkah berikutnya dapat dirumuskan alternatif dan rancangan dalam pelaksanaan pembelajaran di kelas

2) Menentukan instruktur atau pendamping kelas; setelah perumusan rencana selesai maka tahapan kedua ialah menetapkan instruktur dan pendamping yang dalam hal ini dimaksudkan untuk membantu pengawasan serta pemberian peer lesson untuk mahasiswa ketika diajak melakukan kunjungan pada perpustakaan yang dimaksud.

3) Materi; materi yang diberikan sudah terintegrasi dan sesuai dengan silabus dan RPS yang sudah tertuang dalam mata kuliah satu semester sehingga mahasiswa bisa langsung terjun mendalami materi tersebut sekaligus dengan uji coba terhadap program penguatan literasi informasi berbasis perpustakaan

4) Metode pengajaran; setelah materi maka desain berikutnya ialah terhadap metode pengajaran dimana metode yang digunakan oleh peneliti ialah metode Active Learning dengan salah satu strateginya ialah Information Search, dimana tujuan strategi tersebut sejalan dengan program Penguatan Literasi Informasi Berbasis Perpustakaan, namun metode ini bukan satu-satunya metode yang digunakan, melainkan terdapat kolaboratif antar beberapa metode dalam Active Learning yang bisa digunakan untuk Pembelajaran Andragogi

5) Media \& bahan pembelajaran; Penggunaan media dan bahan sangat variatif, menyesuaikan dengan konteks materi serta fasilitas yang ditemukan dilapangan, namun hal tersebut bukan berarti bahwa tidak ada rancangan atu desain sebelumnya, melainkan media 
tersebut ada serta digunakan sesuai dengan tujuan yang saat itu hendak dilakukan.

6) Waktu dan tempat pelaksanaan; Terkait waktu serta pelaksanaan jadwalnya mengikuti siklus yang telah ditetapkan oleh peneliti. Kunjungan ke perpustakaan kampus, perpustakaan Daerah (Perpus 400), Toko Buku Nasional (Gramedia) bergantung pada tahapan siklus yang dilalui, dan siklus yang dilaksanakan pada penelitian ini sejumlah 3 siklus

7) Sarana prasarana; Perilaku mahasiswa saat ke perpustakaan setelah mereka menerima tugas yang harus dikerjakan adalah mereka mencari buku-buku dan sumber informasi lainnya yang relevan dengan materi yang diberikan. Terkadang mereka diajak mencari dari internet (dengan catatan sumber penelusuran dapat dipertanggungjawabkan seperti e-jurnal ataupun situs resmi lainnya), mereka mencari informasi yang diperlukan, mencatatnya dan menyelesaikan tugas mereka.

8) Sistem evaluasi; penilaian yang dilakukan ialah terkait dengan penilaian kinerja, sikap serta produk yang mereka hasilkan, selanjutnya produk tersebut dikumpulkan dalam portfolio sehingga nantinya akan dapat diakumulasikan dengan baik dan detil.
Setelah tahapan dalam implementasi tersebut tuntas dilakukan maka peneliti masih melakukan tahap berikutnya sesuai dengan siklus dalam PTK yang dibahas pada bab lainnya. Adapun terkait manfaat program ini yakni urgensinya dalam penulisan karya ilmiah mahasiswa, meminimalisir plagiarisme serta meningkatkan pengetahuan dan pengalaman mahasiswa. Namun Implementasi literasi informasi ini juga tergantung pada daya tangkap, kondisi fisik dan mental serta pengalaman masing-masing mahasiswa selain itu Penerapan literasi informasi seperti yang tertera di atas, tidak serta merta dapat diterapkan begitu saja ditiap Mata Kuliah. Penerapan informasi sangat bersifat kontekstual, sesuai dengan bagaimana stakeholder, perpustakaan dan kegiatan belajar mengajar itu dapat disinergikan.

c) Efektifitas Penguatan Literasi Informasi Berbasis Perpustakaan Terhadap Peningkatan Mutu

\section{Akademik Mahasiswa PGMI IAIN Cirebon}

Literasi informasi merupakan salah satu kompetensi yang mutlak harus dimiliki oleh mahasiswa di era informasi sekarang ini. Literasi informasi menuntut kemampuan berpikir kritis peserta didik dan kemauan untuk terus menjadi pembelajar seumur hidup sehingga dibutuhkan kesadaran mendalam dari tiap peserta didik untuk meningkatkan literasi mereka. Perkembangan teknologi informasi yang sangat pesat membawa dampak posistif dan negatif bagi masyarakat. Mudahnya 
informasi yang dapat diakses melalui internet justru menimbulkan kebingungan tersendiri bagi pengguna. Salah satu cara yang dapat dilakukan oleh tenaga pendidik ialah memfungsikan kembali perpustakaan, peran perpustakaan salah satunya dapat memberikan pendidikan bagi pemakai dengan fokus pada pengembangan literasi informasi pengguna. Karena keterampilan literasi informasi membutuhkan usaha yang keras dengan konsistensi yang terus menerus serta dukungan dari semua pihak yang terkait.

Dari Pengamatan dan data Kuesioner (survey langsung ke perpustakaan IAIN Cirebon tanggal 7 September 2015) ditemukan fakta bahwa:

1. Mahasiswa PGMI jarang menggunakan pembelajaran di perpustakaan

2. Perpustakaan mulai buka pada jam 0815.00, meskipun jam awal kelas dimulai pada jam 07.00 (sehingga peneliti tatkala akan masuk jam 7 ke perpustakaan jd tertunda).

3. Dosen tidak secara rutin menginstruksikan kepada mahasiswa saat jam kelas untuk ke perpustakaan terkait tugas, mencari informasi atau solusi sendiri.

4. Terdapat mahasiswa yang hampir tidak pernah mengunjungi perpustakaan, dan kurang tahu isi serta lokasi filingnya.

5. Secara umum, pengelola perpustakaan terlihat tidak mempromosikan perpustakaannya (atau berjuang untuk meningkatkan minat baca) secara aktif dan kreatif.

6. Lingkungan kampus (termasuk dosen $\&$ mahasiswa) kurang aktif membangun dan mengembangkan perpustakaan.

Berdasar data penelitian diketahui bahwa sebanyak $57 \%$ mahasiswa masih belum menggunakan referensi dalam pra siklus ini namun ada sebesar $22 \%$ mahasiswa yang telah melek literasi namun belum mengikuti kaidah penulisan yang sesuai dan terdapat $7 \%$ mahasiswa yang telah sempurna menyertakan referensi sesuai dengan kaidah APA Style.

Berdasar data pada siklus 1 terlihat bahwa masih ada sebesar $50 \%$ yang belum menggunakan referensi meski telah diberikan treatment oleh peneliti, namun perubahan terlihat pada prosentase yang menggunakan referensi dengan benar\& lengkap sebesar $14 \%$ atau dua kali lipat dari jumlah pra siklus, dan hal ini menunjukkan adanya efektifitas dalam penguatan program literasi informasi berbasis perpustakaan.

Melihat hasil dari siklus 2 dapat disimpulkan bahwa prosentase terbesar pada siklus 2 ini ialah pada penggunaan referensi sebesar $89 \%$ meskipun jumlah tersebut sebanyak $37 \%$ terdapat referensi yang kurang sempurna, yang dimaksud kurang sempurna pada diagram tersebut ialah kaidah penulisannya yang tidak sesuai dengan APA Style, namun hal ini tetap menunjukkan kemajuan dan efektifitas program penguatan 
literasi berbasis perpustakaan terhadap mutu akademik mahasiswa.

\section{Gbr. Diagram Rekapitulasi}

Ketuntasan Belajar

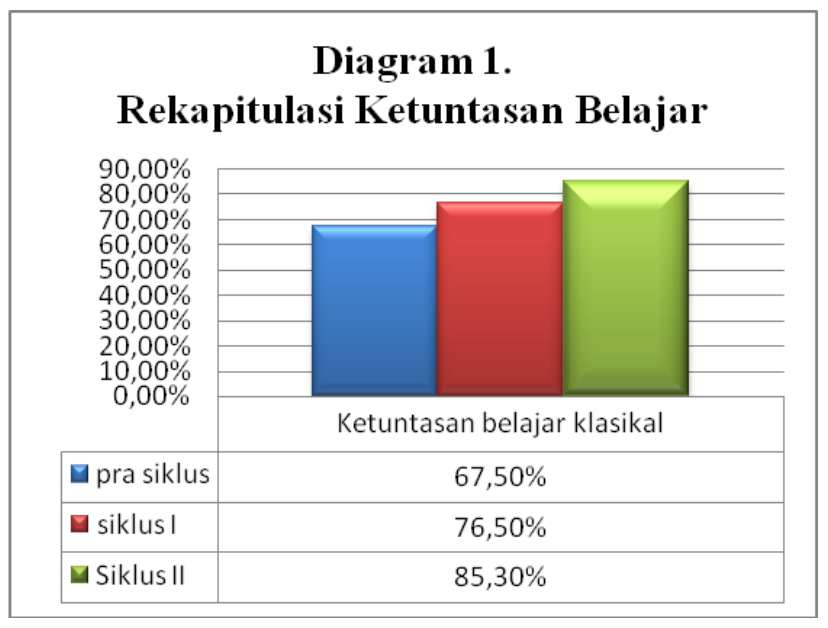

Dari diagram tersebut jelas terlihat bahwa terdapat peningkatan yang cukup konsiten pada tiap jenjangnya, peningkatan tersebut rata-rata sebesar $9 \%$ dalam tiap siklusnya, atau terjadi peningkatan sebesar $17,8 \%$ secara keseluruhan, hal ini menunjukkan bahwa program penguatan literasi informasi berbasis perpustakaan cukup efektif dalam meningkatkan nilai secara kognitif, secara afektif juga mengajarkan kebiasaan positif untuk menelusuri sumber bacaan yang dapat dipertanggungjawabkan dan secara psikomotorik juga menjadikan mahasiswa terampil dalam mengakses sebuah data dan informasi yang akurat dan terpercaya, sehingga terciptalah sisi dan iklim akademis dalam tiap pelibatan tugas mahasiswa.

\section{SIMPULAN}

1. Berdasar hasil observasi dan Collecting data, Unsur yang harus diperhatikan dalam melaksanakan program literasi informasi, yakni target atau sasaran, kebutuhan mahasiswa, metode yang akan digunakan, materi yang akan disampaikan, sumber daya manusia serta fasilitas teknologi yang mendukung. Tiga keterampilan dasar literasi yaitu membaca (reading), menulis (writing), berhitung (arithmatic) serta meneliti (research) bagi Pendidikan Tinggi, maka dengan bekal kemampuan literasi tersebut, setiap mahasiswa memperoleh kesempatan untuk berpartisipasi dan mendapatkan manfaat dari perkembangan informasi saat ini.

2. Implementasi program penguatan literasi informasi berbasis perpustakaan ini terintegrasi dalam kegiatan belajar mengajar di kelas. Adapun tahapan dalam implementasinya yaitu : Merumuskan masalah, Mengidentifikasi dan mengakses informasi, Mengevaluasi sumber informasi dan informasi, Menggunakan informasi, Menciptakan karya, Mengevaluasi karya serta yang terakhir Mengaplikasikan atau Menarik pelajaran dari materi yang diperoleh. Implementasi literasi informasi ini juga tergantung pada daya tangkap, kondisi fisik dan mental serta pengalaman masing-masing mahasiswa selain itu penerapan literasi informasi seperti yang tertera di atas, tidak serta merta dapat diterapkan begitu saja dalam tiap Mata Kuliah. Penerapan informasi sangat bersifat kontekstual, sesuai dengan bagaimana stakeholder, perpustakaan dan kegiatan belajar mengajar dapat disinergikan. 
3. Berdasar data tabulasi hasil nilai tes mahasiswa, dapat disimpulkan bahwa terdapat peningkatan yang efektif terhadap nilai akademis mahasiswa PGMI setelah mereka diberikan tindakan program penguatan literasi informasi berbasis perpustakaan, dimana nilai akademis ini dapat juga dikatakan peningkatan terhadap mutu akademis mahasiswa PGMI. Dari diagram hasil tes jelas terlihat bahwa terdapat peningkatan yang cukup konsisten pada tiap jenjangnya, peningkatan tersebut rata-rata sebesar $9 \%$ dalam tiap siklusnya, atau terjadi peningkatan sebesar 17,8\% secara keseluruhan, hal ini menunjukkan bahwa program penguatan literasi informasi berbasis perpustakaan cukup efektif dalam meningkatkan nilai secara kognitif, dan secara afektif juga mengajarkan kebiasaan positif untuk menelusuri sumber bacaan yang dapat dipertanggungjawabkan serta secara psikomotorik juga menjadikan mahasiswa terampil dalam mengakses sebuah data dan informasi yang akurat dan terpercaya, sehingga terciptalah sisi dan iklim akademis dalam tiap pelibatan tugas mahasiswa.

\section{DAFTAR PUSTAKA}

Artana, I Ketut. 2003. "Perpustakaan, Masyarakat Dan Teknologi Informasi”. Dalam Jurnal Visi Pustaka Vol.5, No.2, Desember 2003 http://www.pnri.go.id/Lists/List\%20M ajalah\%200nline/DispForm.aspx?ID= 57, diakses tanggal 10 Agustus 2015

Carr, Nicholas. 2011. The Shallows; Internet Mendangkalkan cara Berpikir Kita?. Bandung : Mizan

Farmer,Lesley S.J. and Henri, James. 2008. Information Literacy Assessment in $K$ 12 Setting. Maryland: Scarecrow Press.

Godwin, Peter dan Jo Parker (Eds.). 2008. Information literacy meets Library 2.0. London : Facet Publishing.

http://www.bps. go.id/aboutus.php?booklet , diakses tanggal 30 Juli 2015

Indraijaya, Adam I. 1989. Perubahan dan Pengembangan Organisasi. Bandung : Sinar Baru.

Mikkelsen, B. 2001. Metode Penelitian Partisipatoris dan Upaya-upaya Pemberdayaan ; Sebuah Buku Pegangan Bagi Praktisi Lapangan, Terj : Matheos Nalle, Jakarta : Yayasan Obor Indonesia.

Mulyasa, E. 2009. Praktik Penelitian Tindakan Kelas. Bandung : Remaja Rosda Karya

Subagyo, P. Joko. 1991. Metodologi Penelitian dan Praktek. Jakarta : Rineka Cipta. 